DOI: http://dx.doi.org/10.18203/2320-1770.ijrcog20163519

\title{
Pregnancy outcome in elderly primi gravidas
}

\author{
Vibha Moses*, Nilesh Dalal
}

Department of Obstetrics and Gynaecology, MGM Medical College, Indore, Madhya Pradesh, India

Received: 20 September 2016

Accepted: 30 September 2016

\author{
*Correspondence: \\ Dr. Vibha Moses, \\ E-mail: drvibs2815@gmail.com
}

Copyright: (C) the author(s), publisher and licensee Medip Academy. This is an open-access article distributed under the terms of the Creative Commons Attribution Non-Commercial License, which permits unrestricted non-commercial use, distribution, and reproduction in any medium, provided the original work is properly cited.

\begin{abstract}
Background: The health of the mother lays a strong foundation to the health of the nation in general. Pregnancy and child birth are normal physiological processes and outcomes of most pregnancies are good. But pregnancy in woman with advanced age is considered high risk. In obstetric practice, maternal age is an important determinant of the outcome of pregnancy. One such risk factor is an elderly pregnancy that leads to many complications during pregnancy, labor and also for the baby. Elderly Primi Gravida - Women who become pregnant first time after the age of 35 years. In recent times women have changed their life style such as in the pursuit of higher education and entry into work forces and career advancement outside the home. Consequently, this has lead to postponement of child bearing, resulting in an increasing maternal age and it contributes to this upward trend. This study was designed to assess pregnancy outcomes in elderly primigravidas.

Methods: This study was a Prospective hospital based study done in 100 elderly primigravida enrolled after exclusion criteria in M. Y. Hospital and Kalyanmal Nursing Home, MGMMC Indore during Jan. 2015 to Dec. 2015.

Results: This study showed 38\% women postponed their pregnancy due to education and increased maternal complications like Gestational hypertension develop in $24 \%$ elderly primigravida. Gestational diabetes mellitus in $6 \%$, anemia in $19 \%$. Antepartum haemorrhage in $3 \%$. Cesarean section rate $40 \%$. Preterm vaginal delivery $17 \%$. Induction of labour in $11 \%$ and normal delivery only in $29 \%$ and congenital anomaly $3 \%$.

Conclusions: Elderly women are at a high risk of several complications including instrumental deliveries, malpresentations, mal-positions, prolonged labor, increased caesarean section rate, induction of labor, pregnancy induced hypertension, diabetes mellitus, ante and post partum hemorrhage. It was concluded that among maternal pregnancy outcomes PPH, Induction of labour and cervical dystocia were found significantly more in elderly primi gravida, fetal pregnancy outcomes such as, Oligohydramnios, Breach and Transverse lie were found significantly more in elderly primigravida. Likewise vaginal deliveries were significantly less in elderly primi gravida. IUGR and low birth weight was significantly higher in newborns of elderly primi gravida.
\end{abstract}

Keywords: Elderly primigravida, Pregnancy, Maternal complication

\section{INTRODUCTION}

The health of the mother lays a strong foundation to the health of the nation in general. Pregnancy and child birth are normal physiological processes and outcomes of most pregnancies are good. but pregnancy in woman with advanced age is considered high risk. ${ }^{1}$ In obstetric practice, maternal age is an important determinant of the outcome of pregnancy and both extremes are known to be associated with adverse maternal and fetal outcome One such risk factor is an elderly pregnancy that leads to many complications during pregnancy, labour and also for the baby.

\section{Elderly Primi Gravida}

Women who become pregnant first time after the age of 35 years. $^{2}$ In recent times women have changed their life style such as in the pursuit of higher education and entry into work forces and career advancement outside the 
home. Consequently, this has led to postponement of child bearing, resulting in an increasing maternal age and increase in the rate of divorce followed by remarriage etc. contributes to this upward trend.

Elderly women are at a high risk of several complications including instrumental deliveries, mal-presentations, malpositions, prolonged labour, increased caesarean section rate, induction of labour, pregnancy induced hypertension, diabetes mellitus, antepartum and post partum haemorrhage. ${ }^{3}$ The elderly primigravida is generally believed to have decreased fertility and increased risk for adverse pregnancy outcomes. ${ }^{4}$ Reduced fertility with increasing maternal age is evidenced by decline in ovarian oocyte reserve and quality with increasing number of ovulatory cycles poor oocyte quality is associated with an increased risk for aneuploidy, chromosomal abnormalities, and spontaneous abortions in this group of women who are routinely screened for these problems in some countries. ${ }^{5}$

In recent times, women have changed their life style such as in the pursuit of higher education and entry into work forces and career advancement outside the home. Consequently, this has led to postponement of child bearing, resulting in an increasing maternal age and increase in the rate of divorce followed by remarriage etc. contributes to this upward trend. Traditionally such women are considered to be high risk obstetric patients because of the complications associated with their pregnancies and deliveries. This study was designed to assess pregnancy outcomes in elderly primigravida.

\section{METHODS}

This was a hospital based prospective observational study. This study was conducted in Department of Obstetrics and Gynaecology, M.G.M. Medical College and Kalyanmal Nursing Home of Hospitals, Indore during a period from January 2015 to December 2015. This study was approved by subject committee and permission obtained from the hospital authority where this study was conducted.

All women having age $>35$ years elderly primigravida were enrolled in this study after their admission in the hospital. A total of 100 cases were enrolled in the study.

The labour ward register and case records were used of all elderly primigravida women delivered and details of these patients were recorded in the proforma.

\section{Exclusion criteria}

- Married women who have age $<35 \mathrm{yr}$.

- Married women who have underwent permanent sterilization.

- Multiple gestation, patients having major respiratory, heart disease.

\section{RESULTS}

Table 1: Age wise Distribution of cases.

\begin{tabular}{|lll|}
\hline $\begin{array}{l}\text { Age wise distribution } \\
\text { of cases }\end{array}$ & No. of cases & Percentage \\
\hline 35-36 years & 46 & $46 \%$ \\
\hline $36-37$ years & 30 & $30 \%$ \\
\hline $38-39$ years & 20 & $20 \%$ \\
\hline$>40$ years & 4 & $4 \%$ \\
\hline Total & 100 & $100 \%$ \\
\hline
\end{tabular}

Table 2: Distribution of cases according to years between marriage and birth.

\begin{tabular}{|lll|}
\hline Year of Marriage & No. of Patients & Percentage \\
\hline$<2$ years & 51 & $51 \%$ \\
\hline $3-5$ years & 41 & $41 \%$ \\
\hline$>5$ years & 8 & $8 \%$ \\
\hline
\end{tabular}

Table 3: Distribution of cases according to reason for postponing child bearing.

\begin{tabular}{|lll|}
\hline Reason of postponed & No. of Patients & Percentage \\
\hline Occupation & 22 & $22 \%$ \\
\hline Education & 38 & $38 \%$ \\
\hline Infertility & 4 & $4 \%$ \\
\hline Social & 20 & $20 \%$ \\
\hline Others & 16 & $16 \%$ \\
\hline
\end{tabular}

Table 4: Distribution of cases according to educational status.

\begin{tabular}{|lll|}
\hline Socioeconomic status & No. of Patients & Percentage \\
\hline Illiterate & 22 & $22 \%$ \\
\hline High school & 30 & $30 \%$ \\
\hline Higher secondary & 28 & $28 \%$ \\
\hline $\begin{array}{l}\text { Graduate / } \\
\text { postgraduate }\end{array}$ & 20 & $20 \%$ \\
\hline Total & 100 & $100 \%$ \\
\hline
\end{tabular}

Table 5: Maternal complications in elderly primi gravid.

\begin{tabular}{|lll|}
\hline Antenatal complications & No. of cases & Percentage \\
\hline Gestational hypertension & 24 & $24 \%$ \\
\hline GDM & 6 & $6 \%$ \\
\hline Anaemia & 19 & $19 \%$ \\
\hline Antepartum Haemorrhage & 3 & $3 \%$ \\
\hline H/o of Abortion & 7 & $7 \%$ \\
\hline breech & 6 & $6 \%$ \\
\hline Pregnancy with Fibroids & 5 & $5 \%$ \\
\hline oligohydramnios & 10 & 10 \\
\hline Hypothyroidism & 3 & $3 \%$ \\
\hline Preeclampsia & 4 & $4 \%$ \\
\hline other & 13 & $13 \%$ \\
\hline
\end{tabular}


Table 6: Mode of delivery in elderly primi gravida.

\begin{tabular}{|lll|}
\hline Diagnosis & No. of Patients & Percentage \\
\hline Normal labour & 29 & $29 \%$ \\
\hline LSCS & 40 & $40 \%$ \\
\hline Preterm labour & 17 & $17 \%$ \\
\hline Induced labour & 11 & $11 \%$ \\
\hline $\begin{array}{l}\text { Assisted breech } \\
\text { delivery }\end{array}$ & 1 & $1 \%$ \\
\hline TVSD & 2 & $2 \%$ \\
\hline Total & 100 & $100 \%$ \\
\hline
\end{tabular}

Table 7: Various causes of perinatal outcome.

\begin{tabular}{|lll|}
\hline Perinatal outcome & No. of cases & Percentage \\
\hline Congenital anomaly & 3 & $3 \%$ \\
\hline IUGR+lbw & 22 & $22 \%$ \\
\hline Still Birth & 2 & $2 \%$ \\
\hline Other & 73 & $73 \%$ \\
\hline Total & 100 & 100 \\
\hline
\end{tabular}

\section{DISCUSSION}

The present study was a hospital based prospective study, conducted over the period of one year. The study included 100 elderly primigravida $>35$ years of age. All the cases were evaluated till delivery for maternal and fetal complications and outcome. A definite increase in the number of women bearing children in their 30's and 40 's is expected to occur both in developing and developed countries. Women's career priorities, tertiary education, availability of fertility control, late and second marriages, changes in socio-cultural patterns and mores are some of the common factors affecting postponement of childbearing. Postponement of marriage in the Indian women may be due to a lack of opportunity to meet the right partners Amrin et al. ${ }^{6}$ Very often this is due to high literacy rates amongst these women. Teachers, civil servants and other female professionals serving in the rural areas lack the opportunity of meeting men of equal social standing.

\section{Age group}

$96 \%$ belonged to $35-40$ years, $4 \%$ belonged to $41-45$ age groups. The mean age group was 36.8 years in this study (Table 1). Marriage to conception interval in elderly primi gravida was analyzed and found that $51 \%$ the interval was $<2$ years, $41 \%$ interval was 3-5 years and $8 \%$ interval was $>5$ years of marital age (Table 2 ).

Pregnancy in women of advanced age is considered a high risk. This concept has been diffused into the health delivery system of the country and prompt referral of these patients for consultation and care is made. Improvement of pregnancy outcome should be anticipated with the availability of amniocentesis, cytogenetics, electronic fetal monitoring and ultrasonography. Except for the latter, the other facilities were not available at this hospital during the period of study. Clinical supervision was largely relied on in management of the cases.

\section{Complications in pregnancy}

The elderly primigravida is more likely to encounter complications which are the result of the natural process of ageing. It was noted that $87(87 \%)$ out of the 100 cases included in the study group had antenatal complications. Infect, the risk of antenatal complications were about three times higher in the women of age group 35 years and above. Complications of early pregnancy like abortions have been observed in 7 cases. Pregnancy induced hypertension occurred in $24 \%$ of elderly primigravidae. This is significantly higher when compared with Sahu T Meenakshi et al $10 \%$ of the complication in primigravidae. ${ }^{7}$ Abruptio placentae occurred in 3\% patients in present study which are similar to above study. Diabetes mellitus was $6 \%$ which are higher to Rajmohan Laxmi et al. ${ }^{8}$ The frequency of this metabolic disorder was increased among primiparas aged 35 and above Naqvi MM et al. ${ }^{9}$ As the patient gets older, she may develop other gynaecological problems. Of these, uterine myoma appears to be the most common. A higher incidence of breech presentation has been reported in elderly primigravida. This high incidence was not related to prematurity, uterine anomaly or fetal anomaly.

\section{Management of labour}

The incidence of preterm labour was $17 \%$. Tocolytic agents play a limited role in management of established preterm labour. The availability of an excellent neonatal care unit may compromise the need for prolongation of pregnancy in these cases.

Patients delivered vaginally $29 \%$, in which instrumental delivery required $6 \%$. Caesarean section was performed on $40 \%$ of cases. ${ }^{10,15}$ Stanton demonstrated an increase in prolonged labour among older pregnant women. Friedman showed an increase in prolonged second stage with advancing age.

An elderly primigravida is anxious and often unsure of her ability to deliver safely. Some degree of uterine inertia may also play a role in causing prolonged labour. Induction and augmentation of labour with oxytocics were carried out in $32 \%$ of the cases. A high intervention rate is a consistent finding in the literature. A caesarean section rate of $17 \%$ was reported by Grimes and Gross compared to $10 \%$ in those under 35 years of age. ${ }^{11}$ These figures are much lower than that reported by other workers. Blum found a higher caesarean section rate $(49 \%)$. In our series the caesarean section rate $(40 \%)$ was four times higher than that of the hospital population. ${ }^{12,16}$ The hospital policy of performing caesarean section for all breech presentations in elderly primigravida may have contributed towards the increased rate. Postpartum 
haemorrhage due to uterine atony was seen in only $3 \%$ patients.

\section{Mortality and morbidity}

There were no maternal deaths in this series. The increased maternal morbidity was due to the increased incidence of hypertension. ${ }^{13}$

Anemia was noted in $19 \%$ of cases in spite of close supervision. This was attributed to failure to take prescribed hemanatemics, food preference and food taboo in pregnancy. A refractory anemia most probably due to a chronic renal pathology was suspected. However, this patient was lost to follow-up after recovering from a caesarean section.

\section{Perinatal mortality and morbidity}

In the present study congenital anomaly was present in $3 \%$, IUGR+LBW babies were $22 \%$, stillbirth $2 \%$ This was in accordance with the findings of Ziadeh et al, Delpisheh A et al who found that the incidence of low birth weight babies is more among elderly nulliparous women a much higher perinatal deaths have been reported in the literature. ${ }^{14,17,19}$ Early booking, close supervision in the antenatal and intrapartum period, appropriately timed obstetric intervention and the advocation of active management of labour may have contributed to good fetal outcome. ${ }^{9}$ Obstetric practice presently has moved away from high cavity forceps delivery and unwarranted breech extraction. The liberal use and early resort to caesarean sections has, however, to be looked upon with caution. Advocation of abdominal delivery purely on the grounds of advanced age should be discouraged.

\section{Management}

Pregnancy in women after 35 years is considered high risk due to the various risks factor so when planning pregnancy and during pregnancy special care given to elderly primi gravida.

\section{Preconceptional counseling}

- Preconceptional counseling is very important in this age group and many women willingly seek it.

- This is very important for women with pre-existing medical problems in which case pregnancy can be planned after stabilizing the medical condition.

2. Prenatal diagnosis

- Prenatal diagnosis is extremely important considering the increased chance of chromosomal defects.

- Ultrasound screening for Down's syndrome is recommended.

- Targeted anomaly scan at $18-20$ weeks is a must.
- Chorion villus sampling (CVS) or amniocentesis may have to perform to rule out chromosomal anomalies.

3. Antepartum management

- More frequent antenatal visits with antepartum fetal surveillance with serial ultrasound and Doppler.

- Opinion of a physician may be necessary, if there are associated medical complications.

4. Intrapartum management

- Close monitoring is indicated in labor.

- Hospital delivery preferably in a tertiary center with good neonatal care facilities is a must.

- CTG monitoring is ideal.

- Judicious monitoring of labor is required.

- A lower threshold for cesarean section is preferred in these women and in many cases, elective cesarean section may be ideal.

- The newborn should be taken care of by an expert neonatologist.

5. Postpartum management

- Elderly primi gravida need better care to avoid postpartum complications and failing lactation.

- They also need contraception advice.

\section{CONCLUSION}

Elderly women are at a high risk of several complications including instrumental deliveries, mal-presentations, malpositions, prolonged labour, increased caesarean section rate, induction of labour, pregnancy induced hypertension, diabetes mellitus, ante and post partum haemorrhage.

It was concluded that among maternal pregnancy outcomes PPH, Induction of labour and cervical dystocia were found significantly more in elderly primi gravida. Maternal pregnancy outcomes such as, Oligohydramnios, Breach and Transverse lie were found significantly more in elderly prim igravida. Vaginal deliveries were significantly less in elderly primi gravida. ${ }^{8}$ Also, IUGR and low birth weight was significantly higher in newborns of elderly primi gravida.

Consistent with other studies, hypertension was the most common disorder complicating pregnancy at age 35 and above. Cases were more likely to undergo induction of labour and operative delivery. Larger studies are needed to establish the exact magnitude of these associations and to show any significant difference in antepartum obstetric problems and fetal and neonatal outcome measures.

Unwarranted intervention in labour based on age alone is not acceptable. Management will largely depend on attempts at improving perinatal outcome without 
compromise to health and well-being of the mother. The perinatal mortality rate was low but the caesarean section rate was high in this study.

Funding: No funding sources

Conflict of interest: None declared

Ethical approval: The study was approved by the Institutional Ethics Committee

\section{REFERENCES}

1. Obed SA, Armah JO, Wilson JB. Advanced maternal age and pregnancy. West Afr J Med. 1995;14(4):198-201.

2. Morrison, I. The elderly primigravida. American Journal of Obstetrics and Gynecology. 1974; 121,465-70.

3. Lavin ER, Samuel H. Wood Essential over 35 Pregnancy guide. 1998.

4. Montan S. Increased risk in the elderly parturient Curr Opin Obstet Gynecol. 2007;19(2):110-2.

5. Van Katwijk C, Peeters LL. Clinical aspects of pregnancy after the age of 35 years. Hum Reprod Update. 1998;4(2):185-94.

6. Amarin VN, Akasheh HF. Advanced maternal age and pregnancy outcome. East Mediterr Health J. 2001;7(4-5):646-51.

7. Meenakshi ST, Agarwal A, Das V. Advanced maternal age and obstetric outcome. J Obstet Gynecol India. 2007;57,4:320-3.

8. Laxmy R, Vinayachandran S, Guhan B, Sumangala DD. Pregnancy Outcome In Women Of Advanced Maternal Age. International Journal of Bioassays. ISSN: 2278-778X.
9. Naqvi MM, Naseem A. Obstetrical risks in the older primigravida. J Coll Physicians Surg Pak. 2004;14(5):278-81.

10. Luke B, Brown MB. Elevated risks of pregnancy complications and adverse outcomes with increasing maternal age. Hum Reprod. 2007;22.

11. Grimes, David A, Gross, Gail K. Pregnancy Outcomes in Black Women Aged 35 and Older obs and gynecology. 1998.

12. Joseph KS, Allen AC, Dodds L, Turner LA, Scott H, Liston R. The Perinatal Effects of Delayed Childbearing. Obstet Gynecol. 2005;105:1410.

13. Nelson. Risk of hypertension as age advances. Br J Obstet Gynecol. 1995;23:169.

14. Ziadeh S. Maternal and perinatal outcome in nulliparous women aged 35 and older. Gynecol Obstet Invest. 2002;54:6-10.

15. Bavrampour H. Comparison of perception of pregnancy risk of nulliparous women in advanced maternal age and younger age. J Midwifery Womens health. 2012;57(5):445-53.

16. Llesanmi AO, Fawole O, Olaleye DO, Arowojolu A. Pregnancy outcome in the elderly primigravidae. J Obstet Gynaecol. 1998.

17. Delpisheh A, Brabin L, Attia E, Brabin BJ. Pregnancy late in life: a hospital- based study of birth outcomes. J Womens Health. 2008.

Cite this article as: Moses V, Dalal N. Pregnancy outcome in elderly primi gravida. Int J Reprod Contracept Obstet Gynecol 2016;5:3731-5. 